\title{
Cytotoxic Activity of Chemical Constituents and Essential Oil from the Leaves of Leonotis nepetifolia (Lamiaceae)
}

\author{
Damasceno, L. M. O.; Silva, A. L. N.; Santos, R. F.; Feitosa, T. A.; Viana, L. \\ G. F.; Oliveira-Júnior, R. G.; Silva, M. G.; Rolim, L. A.; Araújo, C. S.; Araújo, \\ E. C. C.; Delange, D. M.; Pessoa, C. Ó.; Silva, M. F. S.; Almeida, J. R. G. S.;* \\ Oliveira, A. P.
}

Rev. Virtual Quim., 2019, 11 (2), 517-528. Data de publicação na Web: 8 de abril de 2019 http://rvq.sbq.org.br

\section{Atividade Citotóxica de Constituintes Químicos e Óleo Essencial das Folhas de Leonotis nepetifolia (Lamiaceae)}

Resumo: O câncer é um problema de saúde que afeta grande parte da população mundial. Nesse contexto, vários grupos de pesquisa têm investigado moléculas com maior eficiência e menores efeitos colaterais. A espécie Leonotis nepetifolia é um arbusto pertencente à família Lamiaceae com atividade citotóxica relatada na literatura. Este trabalho descreve o isolamento dos compostos hentriacontano, palmitato de fitila, estigmasterol glicosídeo, 6,7-dimetoxi-5,3',4'-trihidroxiflavona, apigenina-7-O-glicosídeo e luteolina-7-O-glicosídeo a partir de extratos e a composição química do óleo essencial das folhas de espécimes brasileiras de L. nepetifolia, além das suas atividades citotóxicas in vitro. Os compostos foram identificados por uma série de métodos espectroscópicos e espectrométricos, principalmente RMN (1D e 2D) e CG-EM, bem como por comparação com dados da literatura. A atividade citotóxica de compostos isolados e óleo essencial foi realizada utilizando o ensaio de brometo de 3-(4,5-dimetiltiazol-2-il)-2,5-difeniltetrazólio (MTT), contra linhagens de células tumorais HCT-116 (cólon humano) e SF-295 (glioblastoma). O álcool 1-octen-3-ol foi o composto majoritário do óleo essencial e os compostos hentriacontano, palmitato de fitila, estigmasterol glicosídeo, apigenina-7-O-glicosídeo e luteolina-7-O-glicosídeo foram descritos pela primeira vez nesta espécie. Todos os compostos testados e o óleo essencial apresentaram baixa atividade citotóxica para as linhagens celulares testadas, sugerindo que outros estudos fitoquímicos devam ser conduzidos para a descoberta de outros compostos responsáveis pela atividade citotóxica da espécie.

Palavras-chave: Produtos naturais; química de produtos naturais; plantas medicinais; Caatinga.

\begin{abstract}
Cancer is a health problem affecting a large part of the world population. In this context, several research groups have investigated molecules with higher efficiency and lower side effects. The species Leonotis nepetifolia is a shrub belonging to the Lamiaceae family with cytotoxicity activity reported in literature. This paper describes the isolation of compounds hentriacontane, phytyl palmitate, stigmasteryl glucoside, 6,7dimethoxy-5,3', 4'trihidroxyflavone, apigenin-7-O-glucoside and luteolin-7-O-glucoside from extracts and the chemical composition of essential oil from the leaves of Brazilian L. nepetifolia species in addition to its in vitro cytotoxic activities. All compounds were identified by a series of spectrometric and spectroscopic methods, mainly NMR (1D and 2D) and GC-MS, as well as by comparison with literature data. The cytotoxic activity of isolated compounds and essential oil was performed using the 3-(4,5-dimethylthiazol-2-yl)-2,5-diphenyltetrazolium bromide (MTT) assay, against tumor cell lines HCT-116 (human colon) and SF-295 (glioblastoma). The alcohol 1-octen-3-ol was the majoritary compound of the essential oil and the compounds hentriacontane, phytyl palmitate, stigmasteryl glucoside, apigenin-7-O-glucoside and luteolin-7-O-glucoside were describes for the first time in this species. All compounds tested and essential oil showed low cytotoxic activity for the cell lines tested, suggesting that other phytochemical studies should be conducted for the discovery of compounds responsible by cytotoxic activity of the species.
\end{abstract}

Keywords: Natural products; chemistry of natural products; medicinal plants; Caatinga.

\footnotetext{
* Universidade Federal do Vale do São Francisco, Núcleo de Estudos e Pesquisas de Plantas Medicinais (NEPLAME), CEP 56304-205, PetrolinaPE, Brazil.

Mjackson.guedes@univasf.edu.br

DOI: $10.21577 / 1984-6835.20190039$
} 


\section{Cytotoxic Activity of Chemical Constituents and Essential Oil from the Leaves of Leonotis nepetifolia (Lamiaceae)}

Lívia M. O. Damasceno, andressa L. N. Silva, ${ }^{a}$ Raíra F. dos Santos, ${ }^{a}$ Thiala A. Feitosa, ${ }^{a}$ Lucas G. F. Viana, ${ }^{a}$ Raimundo G. de Oliveira-Júnior, ${ }^{a}$ Mariana

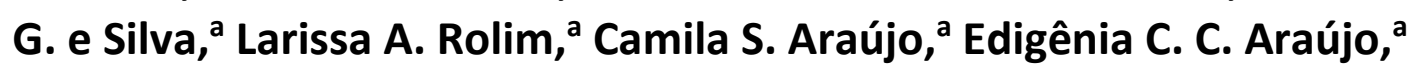
David M. Delange, ${ }^{b}$ Cláudia O. Pessoa, ${ }^{c}$ Maria F. da Silva, ${ }^{c}$ Jackson R. G. S. Almeida, $^{\mathrm{a}, *}$ Ana P. de Oliveira ${ }^{\mathrm{a}}$

\footnotetext{
${ }^{a}$ Universidade Federal do Vale do São Francisco, Núcleo de Estudos e Pesquisas de Plantas Medicinais (NEPLAME), CEP 56304-205, Petrolina-PE, Brasil.

${ }^{b}$ Center of Marine Bioproducts (CEBIMAR), Havana, Cuba

c Universidade Federal do Ceará, Laboratório Nacional de Oncologia Experimental, CEP 60430-270, Fortaleza-CE, Brasil.

* jackson.guedes@univasf.edu.br
}

1. Introduction

2. Experimental

2.1. General experimental procedures

2.2. Plant material

2.3. Preparation of extracts

2.4. Extraction of essential oil

2.5. Isolation of constituents

2.6. Cytotoxic activity

\section{Results and Discussion}

3.1. Characterization of essential oil

3.2. Isolated constituents

3.3. Cytotoxic activity

\section{Conclusion}

\section{Introduction}

Cancer is a disease characterized by uncontrolled cell growth and division.
Nowadays, cancer is one the major death causes in the world. Only in 2012, $15 \%$ of deaths worldwide were attributable to this disease and the reports have shown which approximately 17 million cancer deaths per 
year might occur by $2030 \cdot{ }^{1-4}$ Chemotherapy is a major treatment for cancer, however, it is very expensive and shows pronounced side effects. These problems show the necessity in discovery of new drugs able to overcome the limitations of the current therapies. ${ }^{1-5}$

The use of natural products for treatment of diseases is as long as the history of humanity. The World Health Organization (WHO) reported that about $80 \%$ of the world's population still relies on traditional system of medicine. Until today, natural products are a rich source for discovery of new drugs for the treatments of many diseases including cancer, because the diversity of compounds produced by plants, microorganisms, marine organisms and others. ${ }^{6-7}$

Leonotis nepetifolia is an African herbaceous plant belonging to Lamiaceae family and widely distributed in southern India and America. In Brazil, this species is popularly known as "cordão-de-São Francisco", "cordão-de- frade" and "rubim" and in the folk medicine, is used to treat stomach ulcers and as antidiarrheal, anti-inflammatory, expectorant, anti-asthmatic, antipyretic, digestive and sedative. ${ }^{8-9}$

Reports involving this species have showed the presences of fixed oils, essential oils, terpenoids, saponins, flavonoids, steroids, alkaloids, iridoids and coumarins. ${ }^{8 ;} 10-19$ A previous study developed by our research group showed the cytotoxic activity of $L$. nepetifolia in human and murine cell lines. ${ }^{20}$ Thus, the aim of this study was to investigate the cytotoxic potential of the isolated compounds and the essential oil from a $L$. nepetifolia Brazilian specimen.

\section{Experimental}

\subsection{General experimental procedures}

The chemical analysis of $L$. nepetifolia (essential oil and compounds 1 and 2) was performed in a semi quantitative way on a
Shimadzu QP-2010 Gas Chromatograph interfaced to a mass spectrometer (GC-MS). The following conditions were used: DB-5MS column Agilent Technologies $(30 \mathrm{~m} \times 0.25 \mathrm{~mm}$ $\times 0.25 \mu \mathrm{m})$; helium $(99.999 \%$ ) carrier gas at a constant flow of $1.1 \mathrm{ml} / \mathrm{min} ; 1.0 \mu \mathrm{L}$ injection volume; injector split ratio of $1: 10$; injector temperature $250{ }^{\circ} \mathrm{C}$; electron impact mode at $70 \mathrm{eV}$; ion-source temperature $280{ }^{\circ} \mathrm{C}$ and transfer line temperature $260{ }^{\circ} \mathrm{C}$. The oven temperature was programmed from $60{ }^{\circ} \mathrm{C}$ to $240{ }^{\circ} \mathrm{C}$ at a temperature ramp of $3{ }^{\circ} \mathrm{C} / \mathrm{min}$. A mixture of linear hydrocarbons $\left(\mathrm{C}_{8} \mathrm{H}_{18}-\mathrm{C}_{40} \mathrm{H}_{82}\right)$ was injected under the same experimental conditions that the samples and the identification of the constituents was performed by comparing the mass spectra obtained with those of the equipment database (Wiley 7 lib and NIST 08 lib), using the Kovats Index. Data were processed with help of the Shimadzu GC-MS Solution software. All 1D and 2D NMR spectra were obtained in a Bruker spectrometer Ascend ${ }^{\mathrm{TM}}$ 400 model with $400 \mathrm{MHz}\left({ }^{1} \mathrm{H}\right)$ and $100 \mathrm{MHz}$ $\left({ }^{13} \mathrm{C}\right)$ and shifts $(\delta)$ in ppm. The samples were solubilized in DMSO- $d_{6}, \mathrm{MeOD}$ or $\mathrm{CDCl}_{3}$ using TMS as internal standard.

\subsection{Plant material}

For isolation of compounds from Leonotis nepetifolia, the plant material (leaves) was collected in March 2014 and September 2016. For extraction of essential oil, the leaves were collected in January of 2015. All specimens were collected in Petrolina, state of Pernambuco, Brazil. The specimens were compared with the voucher (\#5266), deposited at Herbário Vale do São Francisco (HVASF) in Universidade Federal do Vale do São Francisco. All procedures for access to genetic patrimony and associated traditional knowledge were carried out and the project was registered in SisGen (Register \#A7F117F and \#A459D5B). 


\subsection{Preparation of extracts}

The leaves were dried in an oven at $40{ }^{\circ} \mathrm{C}$ during $72 \mathrm{~h}$. Then, the plant material was powdered and subjected to maceration with ethanol $95 \%$. The extractive solution was concentrated under vacuum on a rotatory evaporator at $50{ }^{\circ} \mathrm{C}$, yielding $8.039 \mathrm{~g}$ of the crude ethanol extract (CEE-Ln-2014). The fractions were obtained by liquid chromatography under vacuum with hexane, chloroform, ethyl acetate and methanol in ascending order of polarity. ${ }^{20}$ For the leaves collected in 2016, the plant material was also dried in an oven at $40{ }^{\circ} \mathrm{C}$ during $72 \mathrm{~h}$ and powdered in a mill. Then, it was extracted using ultrasonic apparatus with hexane, chloroform, ethyl acetate and methanol in ascending order of polarity.

\subsection{Extraction of essential oil}

The leaves (745.0 g) were mashed and extracted by hydrodistillation for 2 hours in a Clevenger modified apparatus with petroleum ether as facilitator solvent drug. ${ }^{14}$ The essential oil was refrigerated and separate from the water phase. The percent of extractions were calculated as relationship of mass of essential oil by mass of fresh leaves from the mass of the essential oil obtained.

\subsection{Isolation of constituents}

The chloroform fraction (CF-Ln-2014) (900 $\mathrm{mg}$ ) was subjected to a column chromatography with silica gel as stationary phase and eluted with hexane, chloroform and methanol individually or as binary mixture, yielding 232 fractions. The fractions were grouped in 29 groups, and the fractions 1-38 and 39-40 were codified as compounds 1 $(36.4 \mathrm{mg}$ ) and $2(37.1 \mathrm{mg})$, respectively.

The ethyl acetate fraction (AcF-Ln-2014) (3.67 g) was chromatographed over a silica gel column eluted with chloroform, ethyl acetate and methanol, individually or as binary mixture yielding 19 fractions. The solid observed in the fraction 17 was washed with chloroform and identified as compound 3 (5.0 $\mathrm{mg})$. The rest of fractions were grouped and the fraction 14-15 was subjected to silica gel column chromatography eluted with hexane, ethyl acetate and methanol, individually or as binary mixture yielding 163 fractions. The solid of the fraction 15 was successively washed with chloroform and identified as compound 4 ( $27.8 \mathrm{mg}$ ).

The second ethyl acetate fraction (AcF-Ln2016) (1.59 g) also was chromatographed over a silica gel column and eluted with chloroform, ethyl acetate and methanol, individually or as binary mixture yielding 41 fractions. The factions 33-37 were grouped and chromatographed by exclusion molecular using Sephadex as stationary phase, methanol as eluent and at end 49 fractions was obtained. The subfractions 24-26 and 2729 were grouped and identified as compound $5(36.8 \mathrm{mg})$ and $6(31.2 \mathrm{mg})$ respectively.

Hentriacontane (1): White, crystalline solid; $\mathrm{C}_{31} \mathrm{H}_{64}$; MW 436.00 (g/mol); El-MS $\mathrm{m} / \mathrm{z}$ : 141, 113, 99, 85, 71 and 57 (base peak). ${ }^{1} \mathrm{H}$ NMR (400 MHz, $\left.\mathrm{CDCl}_{3}\right) \delta_{\mathrm{H}}$ (ppm): 0.84-1.36; ${ }^{13} \mathrm{C}$ NMR $\left(100 \mathrm{MHz}, \mathrm{CDCl}_{3}\right) \delta_{\mathrm{C}}(\mathrm{ppm}): 14.11$, 22.70, 29.37, 29.71, 31.94.

Phytyl palmitate (2): Colorless, crystalline solid; $\mathrm{C}_{36} \mathrm{H}_{70} \mathrm{O}_{2} ; \mathrm{MW} 534.00$ (g/mol); El-MS $m / z: 278,123,95,68,57$ (base peak). ${ }^{1} \mathrm{H}$ NMR $\left(400 \mathrm{MHz}, \mathrm{CDCl}_{3}\right) \delta_{\mathrm{H}}(\mathrm{ppm}): 2.3(2 \mathrm{H}, \mathrm{t}), 4.59$ $(1 \mathrm{H}, \mathrm{d}, J=6.98), 5.31(1 \mathrm{H}, \mathrm{t}) ;{ }^{13} \mathrm{C}$ NMR $(100$ $\mathrm{MHz}, \mathrm{CDCl}_{3}$ ) $\delta_{\mathrm{c}}(\mathrm{ppm}): 14.12$ (C-16'), 16.38 (C3a), 19.72 (C-7a), 19.76 (C-11a), 22.63 (C-16), 22.70 (C-5), 22.72 (C-15a), 22.84 (C-13), 24.48 (C-14), 25.05 (C-12), 27.99 (C-15), 29.129.71(C-3'-15'), 31.94 (C-10), 32.69 (C-7), 32.81 (C-11), 34.43 (C-2'), 37.32 (C-8), 37.39 (C-6), 37.44 (C-9), 39.87 (C-4), 61.20 (C-1), 118.22 (C-2), 142.59 (C-2), 173.94 (C-1').

Stigmasteryl glucoside (3): White, amorphous solid; $\mathrm{C}_{35} \mathrm{H}_{58} \mathrm{O}_{6} ; \mathrm{MW} 574.00$ (g/mol); ${ }^{1} \mathrm{H}$ NMR (400 MHz, $\left.\mathrm{CDCl}_{3}\right) \delta_{\mathrm{H}}$ (ppm): $3.04(1 \mathrm{H}, \mathrm{m}) ; 3.64$ (2H, dd); 4.21 (H1, d); 5.04 
$(1 \mathrm{H}, \mathrm{dd} ; J=8.4 \mathrm{~Hz}) ; 5.18(1 \mathrm{H}, \mathrm{dd} ; J=8.4 \mathrm{~Hz})$; $5.31(1 \mathrm{H}, \mathrm{m}) ;{ }^{13} \mathrm{C}$ NMR $\left(100 \mathrm{MHz}, \mathrm{CDCl}_{3}\right) \delta_{\mathrm{c}}$ (ppm): 11.63 (C-18), 11.74 (C-29), 19.06 (C19), 19.60 (C-27), 20.55 (C-11), 20.80 (C-21), 21.06 (C-26), 23.82 (C-15), 25.42 (C-28), 28.44 (C-16), 30.69 (C-2), 31.28 (C-25), 31.33 (C-7), 31.38 (C-8), 36.18 (C-10), 36.79 (C-1), 38.28 (C4), 39.20 (C-12), 39.70 (C-20), 41.82 (C-13), 49.57 (C-9), 50.54 (C-24), 55.31 (C-17), 56.22 (C-14), 76.80 (C-3), 121.16 (C-6), 128.80 (C23), 137.98 (C-22), 140.43 (C-5).

\section{6,7-dimethoxy-5,3',4'-trihidroxyflavone}

(4): Yellow, amorphous solid; $\mathrm{C}_{17} \mathrm{H}_{14} \mathrm{O}_{7}$; LC-ESIMS/MS [M+H] 331.05, $\mathrm{MS}^{2}$ 186.16; ${ }^{1} \mathrm{H}$ NMR (400 MHz, DMSO) $\delta_{\mathrm{H}}$ (ppm): $3.71\left(3 \mathrm{H}, \mathrm{s}, \mathrm{OCH}_{3}-\right.$ 6). $3.91\left(3 \mathrm{H}, \mathrm{s}, \mathrm{OCH}_{3}-7\right) ; 6.71(1 \mathrm{H}, \mathrm{s}, \mathrm{H}-3) .6 .87$ $(1 \mathrm{H}, \mathrm{H}-8), 6.88\left(1 \mathrm{H}, \mathrm{d}, J=8.00, \mathrm{H}-5^{\prime}\right), 7.42(1 \mathrm{H}$, $\left.\mathrm{d}, J=2.11, \mathrm{H}-2^{\prime}\right), 7.44(1 \mathrm{H}, \mathrm{dd}, J=2.11$ and 8.00, H-6 $), 12.92(\mathrm{OH}-12) .{ }^{13} \mathrm{C}$ NMR $(100 \mathrm{MHz}$,

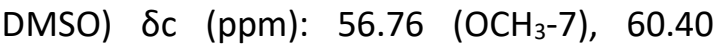
$\left(\mathrm{OCH}_{3}-6\right), 91.82$ (C-8), 103.15 (C-3), 105.53 (C10), 113.92 (C-2'), 116.39 (C-5'), 119.47 (C-6'), 121.93 (C-1'), 132.36 (C-6), 146.25 (C-3'), 150.30 (C-4'), 152.59 (C-5), 153.08 (C-9), 159.074 (C-7), 164.75 (C-2), 182.58 (C-4).

Apigenin 7-O-glucoside (5a): Green, amorphous solid; $\mathrm{C}_{21} \mathrm{H}_{20} \mathrm{O}_{10}$; LC-ESI-MS/MS $[\mathrm{M}+\mathrm{H}]$ 433.10, $\mathrm{MS}^{2}: 271.02 ;{ }^{1} \mathrm{H}$ NMR (400 $\mathrm{MHz}, \mathrm{DMSO}) \delta_{\mathrm{H}}(\mathrm{ppm}): 3.19\left(1 \mathrm{H}, \mathrm{t}, \mathrm{H}-4^{\prime \prime}\right), 3.28$ $\left(1 \mathrm{H}, \mathrm{m}, \mathrm{H}-2^{\prime \prime}\right), 3.31\left(1 \mathrm{H}, \mathrm{m}, \mathrm{H}-5^{\prime \prime}\right), 3.43(1 \mathrm{H}, \mathrm{m}$, $\left.H-3^{\prime \prime}\right), 3.46\left(1 \mathrm{H}, \mathrm{m}, \mathrm{H}-6^{\prime \prime}\right), 3.70\left(1 \mathrm{H}, \mathrm{d}, \mathrm{H}-6^{\prime \prime}\right)$, $5.08\left(1 \mathrm{H}, \mathrm{d}, J=3.3 \mathrm{~Hz}, \mathrm{H}-1^{\prime \prime}\right), 6.44(1 \mathrm{H}, \mathrm{H}-6)$, $6.84(1 \mathrm{H}, \mathrm{d}, J=2.09 \mathrm{~Hz}, \mathrm{H}-6), 6.88(1 \mathrm{H}, \mathrm{s}, \mathrm{H}-3)$, $6.96\left(2 \mathrm{H}, \mathrm{d}, J=8.9 . \mathrm{H}-3^{\prime}\right.$ and $\left.\mathrm{H}-5^{\prime}\right), 7.97(2 \mathrm{H}, \mathrm{d}$, $J=8.9 \mathrm{~Hz}, \mathrm{H}-2^{\prime}$ and $\left.\mathrm{H}-6^{\prime}\right), 13.02(\mathrm{OH}-12) .{ }^{13} \mathrm{C}$

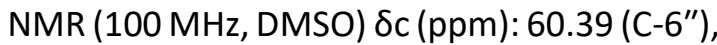
69.34 (C-4"), $72.96\left(\mathrm{C}-2^{\prime \prime}\right), 76.29$ (C-5"), 77.01 $\left(C-3^{\prime \prime}\right), 94.64$ (C-6), 99.36 (C-8), 99.69 (C-1"), 102.83 (C-3), 105.17 (C-10), 115.92 (C-3' and $\left.C^{-}-5^{\prime}\right), 120.75\left(C-1^{\prime}\right), 128.48$ (C-2' and $\left.C-6^{\prime}\right)$, 156.80 (C-5), 160.98 (C-9), 161. 40 (C-4'), 162.80 (C-7), 164.40 (C-1), 181.90 (C-4).

Luteolin-7-0-glucoside (5b): Green, amorphous solid; $\mathrm{C}_{21} \mathrm{H}_{20} \mathrm{O}_{11}$; LC-ESI-MS/MS $[\mathrm{M}+\mathrm{H}]$ 449.07, $\mathrm{MS}^{2}:$ 287.03; ${ }^{1} \mathrm{H}$ NMR (400 $\mathrm{MHz}, \mathrm{DMSO}) \delta_{\mathrm{H}}(\mathrm{ppm}): 3.19\left(1 \mathrm{H}, \mathrm{t}, \mathrm{H}-4^{\prime \prime}\right), 3.28$ $\left(1 \mathrm{H}, \mathrm{m}, \mathrm{H}-2^{\prime \prime}\right), 3.31\left(1 \mathrm{H}, \mathrm{m}, \mathrm{H}-5^{\prime \prime}\right), 3.43(1 \mathrm{H}, \mathrm{m}$, $\left.H-3^{\prime \prime}\right), 3.46\left(1 \mathrm{H}, \mathrm{m}, \mathrm{H}-6^{\prime \prime}\right), 3.70\left(1 \mathrm{H}, \mathrm{d}, \mathrm{H}-6^{\prime \prime}\right)$, $5.08\left(1 \mathrm{H}, \mathrm{d}, J=3.3 \mathrm{~Hz}, \mathrm{H}-1^{\prime \prime}\right), 6.44(1 \mathrm{H}, \mathrm{m}, \mathrm{H}-6)$, $6.76(1 \mathrm{H}, \mathrm{s}, \mathrm{H}-3), 6.79(1 \mathrm{H}, \mathrm{d}, J=2.09 \mathrm{~Hz}, \mathrm{H}-6)$, $6.92\left(1 \mathrm{H}, \mathrm{d}, J=9.00 \mathrm{H}-3^{\prime}\right), 7.43(2 \mathrm{H}, \mathrm{d}, J=9.00$ $\left.\mathrm{Hz}, \mathrm{H}-2^{\prime}\right), 7.45\left(1 \mathrm{H}, \mathrm{s}, \mathrm{H}-6^{\prime}\right), 13.02(\mathrm{OH}-12) .{ }^{13} \mathrm{C}$ NMR (100 MHz, DMSO) $\delta c$ (ppm): 60.39 (C-6"), $69.34\left(\mathrm{C}-4^{\prime \prime}\right), 72.96\left(\mathrm{C}-2^{\prime \prime}\right), 76.29\left(\mathrm{C}-5^{\prime \prime}\right), 77.01$ (C-3"), 94.55 (C-6), 99.36 (C-8), 99.69 (C-1"), 102.83 (C-3), 105.17 (C-10), 113.44 (C-6'), 115.92 (C-3'), 119.06 (C-2'), 120.75 (C-1'), 145.71 (C-5'), 150.41 (C-4'), 156.80 (C-5), 160.98 (C-9), 162.80 (C-7), 164.30 (C-1), 181.90 (C-4).

Luteolin-7-0-glucoside (6): Green, amorphous solid; $\mathrm{C}_{21} \mathrm{H}_{20} \mathrm{O}_{11}$; LC-ESI-MS/MS $[\mathrm{M}+\mathrm{H}]$ 449.07, $\mathrm{MS}^{2}: 287.03 ;{ }^{1} \mathrm{H}$ NMR $(400$ $\mathrm{MHz}, \mathrm{MeOD} \delta_{\mathrm{H}}$ (ppm): $3.41\left(1 \mathrm{H}, \mathrm{m}, \mathrm{H}-3^{\prime \prime}\right), 3.49$ $\left(1 \mathrm{H}, \mathrm{m}, \mathrm{H}-2^{\prime \prime}\right), 3.53\left(1 \mathrm{H}, \mathrm{m}, \mathrm{H}-4^{\prime \prime}\right), 3.55(1 \mathrm{H}, \mathrm{m}$, H-5"), $3.75\left(1 \mathrm{H}, \mathrm{d}, J=3.3 \mathrm{~Hz}, \mathrm{H}-6^{\prime \prime}\right), 3.93(1 \mathrm{H}$, $\left.\mathrm{d}, J=3.3 \mathrm{~Hz}, \mathrm{H}-6^{\prime \prime}\right), 5.07\left(1 \mathrm{H}, \mathrm{d}, \mathrm{H}-1^{\prime \prime}\right), 6.49(1 \mathrm{H}$, $\mathrm{d}, J=1.98, \mathrm{H}-8), 6.61(1 \mathrm{H}, \mathrm{s}, \mathrm{H}-3), 6.80(1 \mathrm{H}, \mathrm{d}$, $J=1.98 \mathrm{~Hz}, \mathrm{H}-6), 6.91\left(1 \mathrm{H}, \mathrm{d}, J=8.78 \mathrm{~Hz}, \mathrm{H}-3^{\prime}\right)$, $7.41\left(1 \mathrm{H}, \mathrm{d}, J=8.78 \mathrm{~Hz}, \mathrm{H}-2^{\prime}\right), 7.43(1 \mathrm{H}, \mathrm{s}, \mathrm{H}-$ $\left.6^{\prime}\right) .{ }^{13} \mathrm{C}$ NMR (100 MHz, DMSO) $\delta c(p p m):$ 62.54 (C-6"), 71.36 (C-3"), $74.84\left(\mathrm{C}-2^{\prime \prime}\right), 77.9$ (C-4"), 78.5 (C-5"), 95.96 (C-6), 100.87 (C-8), 101.50 (C-1"), 103.8 (C-3), 107.08 (C-10), 114.28 (C-2'), $116.65\left(\mathrm{C}-3^{\prime}\right), 120.42\left(\mathrm{C}-6^{\prime}\right)$, 123.49 (C-1'), 147.15 (C-5'), 151.25 (C-4'), 159.27 (C-5), 162.93 (C-9), 164.84 (C-7), 166.97 (C-2), 184.14 (C-4).

\subsection{Cytotoxic activity}

Human tumor cell lines, HCT-116 (human colon) and SF-295 (glioblastoma) were obtained from the National Cancer Institute (Bethesda, MD, USA). All cells were maintained in RPMI 1640 medium supplemented with $10 \%$ fetal bovine serum, $100 \mathrm{U} / \mathrm{ml}$ of penicillin, and $100 \mu \mathrm{g} / \mathrm{ml}$ of streptomycin at $37{ }^{\circ} \mathrm{C}$ with $5 \% \mathrm{CO}_{2}$. The essential oil and compounds were tested for cytotoxic activity against the tumor cell lines.

Cells were plated at concentrations of $0.7 x$ $10^{5}$ and $0.1 \times 10^{6}$ cells $/ \mathrm{mL}$ for HCT-116 and SF295 strains, respectively. The plates were incubated with the sample for 72 hours in an incubator at $5 \% \mathrm{CO}_{2}$ and $37{ }^{\circ} \mathrm{C}$. At the end, they were centrifuged, and the supernatant removed. Then, it was added $150 \mu \mathrm{L}$ solution 
of 3-(4,5-dimethyl-2-thiazolyl)-2,5-diphenyl$2 \mathrm{H}$-tetrazolium bromide (MTT) and the plates were incubated for $3 \mathrm{~h}$. After incubation, the plates were centrifuged again to remove the MTT solution. The absorbance was read after dissolution of the formazan precipitate with
$150 \mu \mathrm{L}$ pure DMSO in a plate spectrophotometer (595 nm). The cytotoxic effect was quantified as the percentage of the control absorbance of the reduced dye at 595 $\mathrm{nm} .{ }^{21}$ All absorbance values were converted into cell growth inhibition (GI) values, using:

Eq 1. $\quad G I(\%)=100-[(T / C) 100]$

Where, $\mathbf{C}$ was the absorbance for negative control and $\mathbf{T}$ was the absorbance in the presence of the tested sample.

\section{Results and Discussion}

\subsection{Characterization of essential oil}

Light green oil was distilled from the leaves of $L$. nepetifolia. A total of 33 compounds were found from the GC-MS analysis and $93.94 \%$ (31 compounds) were identified by comparison of the data with device libraries (Table 1). In this sample, more than $60.0 \%$ of the identified compounds presented up to 9 carbons in its structures which explains the high volatility of oil. The compounds germacrene $D, \alpha$-humulene, $\alpha$-pinene, 3 octanone, 1,8-cineole, (E)-ocimene, (Z)ocimene, linalool, caryophillene oxide and the major compound 1-octen-3-ol present in the essential oil from the L. nepetifolia, were also reported in the literature for this species and in others Lamiaceae species. $7,13,22,23$

The essential oil from the leaves of Nigerian $L$. nepetifolia specimen showed the compounds $\beta$-caryophyllene and $\alpha$-humulene as majoritary constituents and the 1-octen-3ol as traces. The differences on geography and climate of countries, Caatinga and Savana for
Brazil and Nigeria, respectively, are responsible by differences on oil constitution of Brazilian and Nigerian specimens. ${ }^{7,13}$

\subsection{Isolated constituents}

The structures of the isolated compounds (Figure 1) were confirmed by appropriate spectroscopic methods such as ${ }^{1} \mathrm{H}$ NMR, ${ }^{13} \mathrm{C}$ NMR, GC-MS and LC-ESI-MS. The ${ }^{1} \mathrm{H}$ NMR spectra of compound $\mathbf{2}$ showed a triplet at $5.31 \mathrm{ppm}$ for the olefinic hydrogen and a doublet at 4.59 relative to oxymetilenic hydrogens typical of phytol skeleton. The ${ }^{13} \mathrm{C}$ NMR spectra beyond the typical signal of olefinic carbons $118.2 \mathrm{ppm}$ and $142.60 \mathrm{ppm}$ typical of phytol skeleton was observed one signal at $173.94 \mathrm{ppm}$, suggesting the presence of one carbonyl ester in the structure. ${ }^{24}$ Alkyl chain signals also were observed in the ${ }^{13} \mathrm{C}$ NMR spectra and the HMBC spectra showed correlations between the signals at $4.68 \mathrm{ppm}$ and $2.30 \mathrm{ppm}$ with the carbonyl carbon (173.94 ppm) confirming the presence of a phytol ester in the structure. The size of the aliphatic chain was determined by GC-MS. The fragment $m / z 278$ was attributed to the phytol structure and the difference of total mass $\mathrm{m} / \mathrm{z}$ 534 with NMR data allowed getting at the structure of 3,7,11,15-tetramethylhexadec-2enyl palmitate, isolated for the first time in the L. nepetifolia species. 
Table 1. Chemical composition of the essential oil from the leaves of Leonotis nepetifolia

\begin{tabular}{|c|c|c|c|}
\hline Peak & RT (min) & Compound & $(\%)$ \\
\hline 1 & 4.099 & o-Xylene & 2.35 \\
\hline 2 & 4.139 & 4-Methyl-hexanal & 1.31 \\
\hline 3 & 4.551 & m-Xylene & 3.05 \\
\hline 4 & 4.610 & Heptaldehyde & 0.12 \\
\hline 5 & 4.673 & Nonane & 0.57 \\
\hline 6 & 4.807 & Hexa-2,4-dienal & 0.65 \\
\hline 7 & 5.151 & Ethyl disulfide & 0.28 \\
\hline 8 & 5.543 & $\alpha$-Pinene & 0.46 \\
\hline 9 & 5.683 & 4-Methyl-hexanol & 0.51 \\
\hline 10 & 6.507 & 2-Methyl-3,4-dithiahexane & 0.92 \\
\hline 11 & 6.670 & 1-Octen-3-ol & 42.58 \\
\hline 12 & 6.771 & 3-Octanone & 3.75 \\
\hline 13 & 7.006 & Fenchone & 0.75 \\
\hline 14 & 7.171 & Octan-3-ol & 1.58 \\
\hline 15 & 7.272 & (2-Pentenyl)furan & 0.51 \\
\hline 16 & 7.373 & (Z)-3-Hexenyl acetate & 1.28 \\
\hline 17 & 7.929 & Isopropyl disulfide & 0.61 \\
\hline 18 & 8.391 & 1,8-Cineole & 0.73 \\
\hline 19 & 8.515 & (E)-Ocimene & 15.85 \\
\hline 20 & 8.896 & (Z)-Ocimene & 7.01 \\
\hline 21 & 9.289 & 3,7-Dimethyl-undecane & 0.59 \\
\hline 22 & 10.835 & Linalool & 2.05 \\
\hline 23 & 12.022 & 2,6-Dimethyl-2,4,6-octatriene & 0.59 \\
\hline 24 & 18.950 & Dihydroedulan I & 0.41 \\
\hline 25 & 22.515 & $\beta$-Damascenone & 0.92 \\
\hline 26 & 23.104 & $\beta$-Elemene & 1.06 \\
\hline 27 & 24.297 & $\beta$-Caryophyllene & 3.22 \\
\hline 28 & 25.722 & a-Humulene & 1.82 \\
\hline 29 & 26.664 & $\beta$-lonone & 0.83 \\
\hline 30 & 26.783 & Germacrene D & 2.41 \\
\hline 31 & 30.672 & Caryophyllene oxide & 0.72 \\
\hline 32 & 40.489 & $\mathrm{NI}$ & 0.39 \\
\hline 33 & 59.494 & $\mathrm{NI}$ & 0.10 \\
\hline
\end{tabular}

RT: retention time (minutes); (\%) percentage of compound on the sample; NI: Not identified

The ${ }^{1} \mathrm{H}$ NMR spectra of compound 3 showed signals among $0.48-2.90 \mathrm{ppm}$ for methyl and methylene hydrogens, two double doublets at $4.98 \mathrm{ppm}$ and $5.1 \mathrm{ppm}$ corresponding to olefinic hydrogens, a distorted triplet at $5.30 \mathrm{ppm}$ typical of steroid skeletons with double bond in $\mathrm{C}-5$, and the signal at $4.20 \mathrm{ppm}$ characteristic of the one anomeric proton with $J=8.0 \mathrm{~Hz}$, suggesting the presence of one sugar unit with $\beta$ configuration. ${ }^{25}$ 


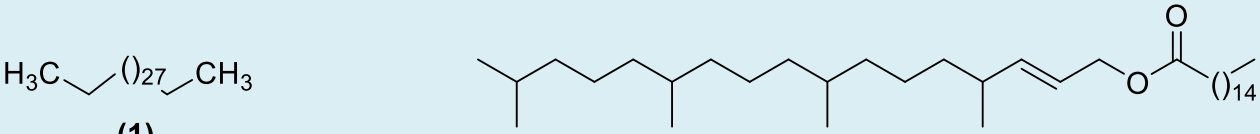

(1)<smiles>CCC(/C=C/[C@H](C)C1CCC2C3CC=C4CC(OC5OC(CO)[C@@H](O)[C@H](O)[C@H]5O)CC[C@]4(C)C3CCC21C)C(C)C</smiles>

(3)<smiles>O=c1cc(-c2ccc(O)cc2)oc2cc(OC3OC(CO)[C@H](O)[C@H](O)[C@H]3O)cc(O)c12</smiles>

(5a)
(2)<smiles>COc1cc2oc(-c3ccc(O)c(O)c3)cc(=O)c2c(O)c1OC</smiles>

(4)<smiles>O=c1cc(-c2ccc(O)c(O)c2)oc2cc(OC3O[C@H](CO)[C@@H](O)[C@H](O)[C@H]3O)cc(O)c12</smiles>

$(5 b, 6)$

Figure 1. Compounds isolated from the leaves of Leonotis nepetifolia

The ${ }^{13} \mathrm{C}$ NMR spectra showed signals characteristic of one sugar unit as the signal at 101.75 ppm, typical of anomeric carbons beyond the six signals in the glycoside region (61.0-77.00 ppm). The olefinic carbons signals at 121.16 and $140.43 \mathrm{ppm}$, at 128.79 and $137.98 \mathrm{ppm}$ related the double bound between $\mathrm{C} 5-\mathrm{C} 6$ and $\mathrm{C} 22-\mathrm{C} 23$, respectively, confirmed the stigmasteryl skeleton. ${ }^{25}$ The correlations between hydrogen at $4.21 \mathrm{ppm}$ of the sugar unit with $\mathrm{C}-3$ of the aglycone at $76.88 \mathrm{ppm}$ showed the linkage of sugar moiety in this carbon. ${ }^{25}$

The MS and NMR data of compound $\mathbf{4}$ are the same as reported in the literature for 6,7dimethoxy-5,3', 4'-trihidroxyflavone (cirsiliol), a flavonoid already reported for $L$. nepetifolia. ${ }^{10,20}$ The ${ }^{1} \mathrm{H}$ NMR spectra of compound 5 showed a mixture of two flavonoids with typical multiplicity for rings $B$ of flavonoids 1,4-substituted and 1,3,4substituted, respectively. ${ }^{26,27}$ The comparison of all spectroscopic and spectrometric data with literature, ${ }^{26,27}$ allowed affirming the presence of flavonoids apigenin-7-O-glucoside and luteolin-7-O-glucoside in mixture and still that the compound 6 it was the flavonoid luteolin-7-O-glucoside.

\subsection{Cytotoxic activity}

Cytotoxicity analysis by the MTT method is commonly used. Large reference centers have used this method, such as the National Cancer Institute $(\mathrm{NCl})$, which tests over 10.000 substances each year. ${ }^{28}$ It is a fast, sensitive and inexpensive method. It was first described by Mosman (1983) and allows analyzing the viability and the metabolic state of the cell. It is a colorimetric analysis based on conversion of the salt 3-(4,5-dimethyl-2-thiazole)-2,5diphenyl-2-H-tetrazolium bromide (MTT) into formazan blue, by mitochondrial enzymes present only in metabolically active cells. The cytotoxic study by MTT method allows easily 
set the cytotoxicity but not the mechanism of action. $^{29}$

A previous study showed the high potential cytotoxic of $L$. nepetifolia extracts and the compound 6,7-dimethoxy-5, 3',4'trihidroxyflavone (cirsiliol) isolated in this study. ${ }^{20}$ The essential oil, hentriacontane, phytyl palmitate, stigmasteryl glucoside, the mixture of flavonoids apigenin-7-O-glucoside and luteolin-7-O-glucoside and luteolin-7-Oglucoside alone, showed weak activity for the tested strains (Table 2 ). ${ }^{6}$

Table 2. Cell proliferation inhibition (Cl\%) of essential oil and chemical compounds of Leonotis nepetifolia

\begin{tabular}{ccc}
\hline & HCT-116 & SF-295 \\
\hline EO & $16.78 \pm 0.43$ & $13.06 \pm 11.06$ \\
C1 & $26.41 \pm 1.37$ & $00.00 \pm 00.00$ \\
C2 & $32.78 \pm 4.89$ & $12.32 \pm 14.38$ \\
C3 & $47.02 \pm 4.96$ & $23.15 \pm 10.19$ \\
C5(5a/5b) & $13.37 \pm 0.92$ & $00.000 \pm 00.00$ \\
C6 & $11.25 \pm 2.54$ & $2.74 \pm 3.83$ \\
\hline
\end{tabular}

Mean of percentage of cell growth inhibition (Cl\%) of samples at $50 \mu \mathrm{g} \cdot \mathrm{mL}^{-1}$. Values expressed as mean \pm standard error of mean with $n=3$. (EO) essential oil, (C1) Hentriacontane, (C2) Phytyl palmitate, (C3) Stigmasteryl glucoside, (C5), apigenin-7-O-glucoside and luteolin-7-O-glucoside, (C6) luteolin-7-O-glucoside. (HTC 116) human colon and (SF295) glioblastoma

A study developed with 1-oct-3-enol, major compound of essential oil from the leaves of $L$. nepetifolia, revealed a strong cytotoxic activity against human embryonic stem cells. $^{30}$ Although it appears contradictory, the discrepancies between the results of the present study and the realized by Inamdar et al (2012), can be explained by kind of treatment used in the tests and by adopted concentration. In the above study, the authors adopted the airborne exposure technique and a 0-1000 ppm as scale concentration for 1-oct-3-enol while in our study a less $(50 \mu \mathrm{g} / \mathrm{mL})$ and single concentration was used. ${ }^{30}$

Previous reports have showed that stigmasteryl aglycone exhibited a weak antiproliferative activity against hepatic liver (WRL), breast carcinoma (MCF-7), colorectal carcinoma (COLO), T-lymphoblastic leukemia cell line (CEM), cervical carcinoma cell line HeLa and human fibroblasts (BJ) cell lines, at the concentrations of 50 and $100 \mu \mathrm{M} \cdot{ }^{31-32}$ These and ours results show that the sugar unit was not able to potentiate the cytotoxic activity of the stigmasterol molecule.

The presence of flavonoids apigenin-7-Oglucoside and luteolin-7-O-glucoside in species $L$. nepetifolia it's very interesting, although our results have shown a weak cytotoxic activity for mixture of flavonoids and for luteolin-7-O-glucoside, because, these flavonoids are metabolized in its respective aglycones apigenin and luteolin, ${ }^{33}$ whose in vitro cytotoxic activity against tumor line cell $^{34-35}$ and in vivo antitumor activity ${ }^{35}$ have been proven.

\section{Conclusion}

Our study describes for the first time the isolation of hentriacontane, phytyl palmitate, stigmasteryl glucoside, apigenin-7-Oglucoside and luteolin-7-O-glucoside in Leonotis nepetifolia, and the cytotoxic activity for these compounds and essential oil in 
human tumor cell lines. In this context, this paper contributes for the phytochemical study of this vegetal species as well as for the Lamiaceae family.

\section{Acknowledgements}

The authors thank to Brazilian agencies CAPES, CNPq, FACEPE and FUNCAPE for financial support for the work.

\section{References}

${ }^{1}$ Razzaghi-Asl, N.; Miri, R.; Firuzi, O. Assessment of the cytotoxic effect of a series of 1, 4-dihydropyridine derivatives against human cancer cells. Iranian Journal of Pharmaceutical Research 2016, 15, 413. [PubMed][CrossRef]

${ }^{2}$ Szalóki, G.; Krasznai, Z. T.; Tóth, Á.; Vízkeleti, L.; Szöllősi, A. G.; Trencsényi, G.; Balázs, M.; Szabó, G.; Goda, K. The strong in vivo antitumor effect of the UIC2 monoclonal antibody is the combined result of Pgp inhibition and antibody dependent cell-mediated cytotoxicity. PloS One 2014, 9, e107875. [CrossRef]

${ }^{3}$ Brody, H. Cancer. Nature 2014, 509, S49. [CrossRef]

${ }^{4}$ Thun, M. J.; DeLancey, J. O.; Center, M. M.; Jemal, A.; Ward, E. M. The global burden of cancer: priorities for prevention. Carcinogenesis 2009, 31, 100. [CrossRef] [PubMed]

${ }^{5}$ Rathee, P.; Rathee, D.; Rathee, D.; Rathee, S. In-vitro cytotoxic activity of $\beta$-Sitosterol triacontenate isolated from Capparis decidua (Forsk.) Edgew. Asian Pacific Journal of Tropical Medicine 2012, 5, 225. [CrossRef]

${ }^{6}$ Rodrigues, B. S.; Sahm, B. D.; Jimenez, P. C.; Pinto, F. C.; Mafezoli, J.; Mattos, M. C.; Rodrigues-Filho, E.; Pfenning, L. H.; CostaLotufo, L. V.; Oliveira, M. C. F. Bioprospection of cytotoxic compounds in fungal strains recovered from sediments of the Brazilian coast. Chemistry \& Biodiversity 2015, 12, 432. [CrossRef]

${ }^{7}$ Vukovic, N.; Sukdolak, S.; Solujic, S.; Niciforovic, N. Antimicrobial activity of the essential oil obtained from roots and chemical composition of the volatile constituents from the roots, stems, and leaves of Ballota nigra from Serbia. Journal of Medicinal Food 2009, 12, 435. [CrossRef]

${ }^{8}$ Oliveira, D. M.; Melo, F. G.; Balogun, S. O.; Flach, A.; Souza, E. C. A.; Souza, G. P., Rocha, I. N. A.; Costa, L. A. M.; Soares, I. M.; Silva, L. I.; Ascêncio, D.; Martins, D. T. O. Antibacterial mode of action of the hydroethanolic extract of Leonotis nepetifolia (L.) R. Br. involves bacterial membrane perturbations. Journal of Ethnopharmacology 2015, 172, 356. [CrossRef] [PubMed]

${ }^{9}$ Cruz, V. B.; Tresvenzol, L. M. F.; Ferreira, H. D.; Paula, J. R.; Paulino, N. Leonotis nepetifolia (L.) R. Br. (Cordão-de-Frade): biologia e uso tradicional. Revista de Pesquisa e Inovação Farmacêutica 2015, 3, 15. [Link]

10 Li, J.; Fronczek, F. R.; Ferreira, D.; Burandt Jr, C. L.; Setola, V.; Roth, B. L.; Zjawiony, J. K. Bisspirolabdane Diterpenoids from Leonotis nepetaefolia. Journal of Natural Products 2012, 75, 728. [CrossRef]

11 Trivedi, A.; K, S. N.; SH, M. Preliminary pharmacognostic and phytochemical analysis of "Granthika" (Leonotis nepetifolia): an ayurvedic herb. Indian Journal Traditional Knowledge 2011, 10, 682. [Link]

12 Takeda, T.; Narukawa, Y.; Hada, N. Studies on the constituents of Leonotis nepetaefolia. Chemical and Pharmaceutical Bulletin 1999, 47, 284. [CrossRef]

13 Oyedeji, A. O.; Ekundayo, O.; König, W. A. Constituents of the Essential Oil from the Leaves of Leonotis nepetaefolia (L.) Ait. f. Journal of Essential Oil Research 1999, 11, 716. [CrossRef]

${ }^{14}$ Gopal, R. H.; Vasanth, S.; Vasudevan, S. V. Antimicrobial activity of essential oil of Leonotis nepetaefolia. Ancient Science of Life 1994, 14, 68. [PubMed] 
${ }^{15}$ Blount, J. F.; Manchand, P. S. X-Ray structure determination of methoxynepetaefolin and nepetaefolinol, labdane diterpenoids from Leonotis nepetaefolia R. Br. Journal of the Chemical Society, Perkin Transactions 1 1980, 0, 264. [Link]

${ }^{16}$ Purushothaman, K. K.; Vasanth, S.; Connolly, J. D. Nepetaefolinol and two related diterpenoids from Leonotis nepetaefolia. Journal of the Chemical Society, Perkin Transactions 1 1974, 0, 2661. [Link]

${ }^{17}$ Purushothaman, K. K.; Vasanth, S.; Connolly, J. D.; Labbé, C. 4, 6, 7-Trimethoxy-5methylchromen-2-one, a new coumarin from Leonotis nepetaefolia. Journal of the Chemical Society, Perkin Transactions 1 1976, 0, 2594. [Link] [PubMed]

${ }^{18}$ Manchand, P. S. Methoxynepetaefolin, a new labdane diterpene from Leonotis nepetaefolia. Tetrahedron Letters 1973, 14, 1907. [Link]

${ }^{19}$ Bagby, M. O.; Smith Jr, C. R.; Wolff, I. A. Laballenic Acid. A New allenic acid from Leonotis nepetaefolia seed Oil. The Journal of Organic Chemistry 1965, 30, 4227. [CrossRef]

${ }^{20}$ Oliveira, A. P.; Guimarães, A. L.; Pacheco, A. G.; Araújo, C. S.; Júnior, R. G. O.; Lavor, É. M.; Silva, M. G.; Araújo, E. C. C.; Mendes, R. L.; Rolim, L. A.; Costa, M. P.; Farias, H. C. L.; Pessoa, C. Ó.; Lopes, N. P.; Marques, L. M. M.; Almeida, J. R. G. S. Estudo fitoquímico, atividade antimicrobiana e citotóxica de espécimes de Leonotis nepetifolia LR ( $\mathrm{Br}$ ). Química Nova 2016, 39, 32. [CrossRef]

${ }^{21}$ Mosmann, T. Rapid colorimetric assay for cellular growth and survival: application to proliferation and cytotoxicity assays. Journal of Immunological Methods 1983, 65, 55. [CrossRef]

${ }^{22}$ Oyedeji, O. A.; Afolayan, A. J.; Eloff, J. N. Comparative study of the essential oil composition and antimicrobial activity of Leonotis leonurus and L. ocymifolia in the Eastern Cape, South Africa. South African Journal of Botany 2005,71, 114. [CrossRef]

${ }^{23}$ Hamdani, I.; Bouyanzer, A.; Hammouti, B.; Majidi, L.; Costa, J.; Paolini, J.; Chetouani, A.
Chemical composition and antioxidant activity of essential oils of Thymus broussonetii Boiss. and Thymus algeriensis Boiss from Morocco. Asian Pacific Journal of Tropical Disease 2014, 4, 281. [CrossRef]

${ }^{24}$ Correia, S. D. J.; David, J. M.; Silva, E. P. D.; David, J. P.; Lopes, L. M.; Guedes, M. L. S. Flavonoids, norisoprenoids and other terpenes from leaves of Tapirira guianensis. Quimíca Nova 2008, 31, 2056. [CrossRef]

${ }^{25}$ Ahmed, W.; Ahmad, Z.; Malik, A. Stigmasteryl galactoside from Rhynchosia minima. Phytochemistry 1992, 31, 4038. [CrossRef]

26 Švehlíková, V.; Bennett, R. N.; Mellon, F. A.; Needs, P. W.; Piacente, S.; Kroon, P. A.; Bao, Y. Isolation, identification and stability of acylated derivatives of apigenina-7-Oglucoside from chamomile (Chamomilla recutita [L.] Rauschert). Phytochemistry 2004, 65, 2323. [CrossRef]

${ }^{27}$ Chiruvella, K. K.; Mohammed, A.; Dampuri, G.; Ghanta, R. G.; Raghavan, S. C. Phytochemical and antimicrobial studies of methyl angolensate and luteolin-7-0glucoside isolated from callus cultures of Soymida febrifuga. International Journal of Biomedical Science: IJBS 2007, 3, 269. [PubMed]

${ }^{28}$ Skehan, P.; Storeng, R.; Scudiero, D.; Monks, A.; McMahon, J.; Vistica, D.; Warren, J. T.; Bokesch, H.; Kenney, S.;Boyd, M. R. New colorimetric cytotoxicity assay for anticancerdrug screening. JNCl: Journal of the National Cancer Institute 1990, 82, 1107. [CrossRef]

${ }^{29}$ Berridge, M. V.; Tan, A. S.; McCoy, K. D.; Wang, R. The biochemical and cellular basis of cell proliferation assays that use tetrazolium salts. Biochemica 1996, 4, 14.

${ }^{30}$ Inamdar, A. A.; Moore, J. C.; Cohen, R. I.; Bennett, J. W. A model to evaluate the cytotoxicity of the fungal volatile organic compound 1-octen-3-ol in human embryonic stem cells. Mycopathologia 2012, 173, 13. [CrossRef] [PubMed]

${ }^{31}$ Vida, N.; Svobodová, H.; Rárová, L.; Drašar, P.; Šaman, D.; Cvačka, J.; Wimmer, Z. 
Polyamine conjugates of stigmasterol. Steroids 2012, 77, 1212. [CrossRef]

${ }^{32}$ Aiyelaagbe, O. O.; Negi, A. S.; Hamid, A. A.; Luqman, S.; Kumar, S. B.; Kaneez, F. Chemical constituents from Alafia barteri Oliv. Leaves with cytotoxic activity. Journal of the Chinese Chemical Society 2015, 62, 751. [CrossRef]

${ }^{33}$ Kanazawa, K.; Uehara, M.; Yanagitani, H.; Hashimoto, T. Bioavailable flavonoids to suppress the formation of 8-OHdG in HepG2 cells. Archives of Biochemistry and Biophysics 2006, 455, 197. [CrossRef]
${ }^{34}$ Galvez, M.; Martın-Cordero, C.; LopezLazaro, M.; Cortes, F.; Ayuso, M. J. Cytotoxic effect of Plantago spp. on cancer cell lines. Journal of Ethnopharmacology 2003, 88, 125. [CrossRef]

${ }^{35}$ Cai, J.; Zhao, X. L.; Liu, A. W.; Nian, H.; Zhang, S. H. Apigenin inhibits hepatoma cell growth through alteration of gene expression patterns. Phytomedicine 2011, 18, 366. [CrossRef] 